\title{
Environmental Factors Causing Stress in Avicennia marina Mangrove in Rabigh Lagoon Along the Red Sea: Based on a Multi-Approach Study
}

\author{
Mohammed O. Aljahdali ${ }^{1 *}$, Abdullahi B. Alhassan ${ }^{1}$ and Zhaohui Zhang ${ }^{2 *}$ \\ ${ }^{1}$ Department of Biological Sciences, Faculty of Science, King Abdulaziz University (KAU), Jeddah, Saudi Arabia, \\ ${ }^{2}$ Ocean College, Institute of Marine Chemistry and Environment, Zhejiang University, Zhoushan, China
}

OPEN ACCESS

Edited by:

Dongyan Liu,

East China Normal University, China

Reviewed by:

Wilson Thadeu Valle Machado, Fluminense Federal University, Brazil

Zhaoliang Song,

Tianjin University, China

*Correspondence: Mohammed O. Aljahdall moaljahdali@kau.edu.sa Zhaohui Zhang zhaohui_zhang@zju.edu.cn

Specialty section This article was submitted to Marine Ecosystem Ecology, a section of the journal Frontiers in Marine Science

Received: 28 December 2020 Accepted: 15 March 2021 Published: 24 May 2021

Citation:

Aljahdali MO, Alhassan AB and Zhang Z (2021) Environmental Factors Causing Stress in Avicennia marina Mangrove in Rabigh Lagoon Along the Red Sea: Based on a Multi-Approach Study. Front. Mar. Sci. 8:646993. doi: 10.3389/fmars.2021.646993
Lagoons along the Red Sea are socio-economically important but most vulnerable ecosystems. Strong evaporation, strengthened due to global warming, leads to high salinity and high temperature in surface water, which exacerbate physiological stress in mangroves. Rabigh Lagoon is characterized by unusually large spatial differences in nutrient dynamics and physicochemical parameters. We conducted a multi-approach study to demonstrate how environmental factors cause growth retardation and stress in mangroves. There were significant variations $(P<0.05)$ in water salinities and temperatures, nitrogen and phosphorus abundance in sediments, and antioxidants in mangroves among 8 sites across the lagoon. Salinity and water temperature rapidly increased from the northern where Red Sea seawater enters to the southern end, but dissolved oxygen declined. High salinity (44.9), high surface water temperature $\left(28.8^{\circ} \mathrm{C}\right)$ and relatively high nutrients at the southern end of the lagoon (S8) corresponded to high concentrations of antioxidants. High $\delta^{13} \mathrm{C}(-12.4 \%)$ and $\delta^{15} \mathrm{~N}(4.9 \%)$ in the sediments at S8 also reveal relatively high nutrient level due to stagnant water, camel grazing, and runoff bringing in fertilizer from agriculture activities in the catchments during seasonal flooding events. Principal component analyses showed that $\mathrm{N}$ and $\mathrm{P}$ limitation at the lagoon entrance is the leading cause for mangrove stress, while high salinity, temperature, and low dissolved oxygen are the predominant factors for high antioxidants concentrations at the southern end of the lagoon.

\footnotetext{
Keywords: Rabigh Lagoon, mangrove Avicennia marina, stress, antioxidants, stable carbon and nitrogen isotopes, sediments, high salinity, dissolved oxygen
}

\section{INTRODUCTION}

Mangroves play an important role in tropical and subtropical coastal ecosystems by providing food sources, breeding grounds, carbon storage, and protection from coastal erosion (Polidoro et al., 2010; Almahasheer et al., 2016). Mangroves are the most productive plants in the sea in terms of average rates of gross and net primary production. However, edaphic factors such as salinity, waterlogging, tidal frequency, surface hydrology, soil redox potentials, and nutrient limitation have major impacts on tree height and productivity of mangroves (Feller, 1995; Lovelock et al., 2004, 2006; Naidoo, 2009). The growth, stature and productivity of mangroves rely on high levels of nutrients in the soil (Andrews et al., 2004; Alongi, 2011; Jiménez et al., 2011; Ouyang et al., 2017), and optimal salinity (Mckee, 1993; Lovelock et al., 2004; Naidoo, 2009). 
Dwarf mangroves are mature forests that are limited in growth by soil conditions that may include low nutrients, high salinity, or excessive sulfide concentrations. Depletion of key nutrients such as nitrogen and phosphorus often results in scrub or dwarf mangroves (Feller et al., 2003). High salinities could also result in dwarfed plants with small and thick leaves (Patel et al., 2010; Naidoo et al., 2011) as mangroves allocate more biomass resources to roots than shoots (Naidoo and Kift, 2006).

Mangroves are mainly distributed in the riverine delta, where river discharges not only bring abundant nutrient supply to the sediment but also keep salinity at a relatively low level. Therefore, mangrove trees fringing shorelines and rivers are tall and highly productive. However, in areas without riverine inputs, such as islands of South East Asia and the Red Sea, dwarf stature has been documented during the growth of mangroves due to nutrient stress or elevated salinity (Duarte et al., 1998; Lovelock et al., 2004; Almahasheer et al., 2017; Aljahdali and Alhassan, 2020c). Lagoons along the Red Sea are important transition systems providing essential socio-economic goods and services, such as shore protection, fisheries, carbon sequestration, etc. (Aljahdali and Alhassan, 2020a; Aljahdali et al., 2021). However, they possess extremely harsh conditions such as drought, high salinity and high temperature, which constitute an enormous challenge for mangroves.
Rabigh Lagoon, $17 \mathrm{~km}$ long and $3 \mathrm{~km}$ wide, is one of the major lagoons along the Saudi Arabian west coast (Figure 1A). The unusually high salinity allows the lagoon endowed with Avicennia marina only (Aljahdali and Alhassan, 2020a). Mangrove communities are present from coral reefs at the entrance, camel islands in the middle to the southern end of the lagoon (Figure 1B). Seawater from the Red Sea (25 $\sim 30^{\circ} \mathrm{C}$, salinity of $39 \%$ ) enters the Rabigh Lagoon through an open inlet ( $900 \mathrm{~m}$ wide and $2.5 \mathrm{~m}$ deep) as surface inflow. After circulating the lagoon, it exits in the form of subsurface flow (Figure 1B; Aljahdali and Alhassan, 2020a; Aljahdali et al., 2021). Strong evaporation substantially increases both water temperature and salinity along the inflow route. The southern end receives sporadic runoffs through urban regions (Figure 1C), and is characterized by substantially higher organic matter and nutrient concentrations in sediments (Aljahdali et al., 2021). It is essential to understand how the stress in mangroves in Rabigh Lagoon responds to environmental factors as global warming could strengthen evaporation and elevate water temperature in the lagoon.

Here we report a comprehensive study on environmental factors causing stress in mangroves inside Rabigh Lagoon, and to what extent. We collected sediments and mangrove tissues from 8 sites (S1 to S8; Figure 1) along the Red Sea water inflow in

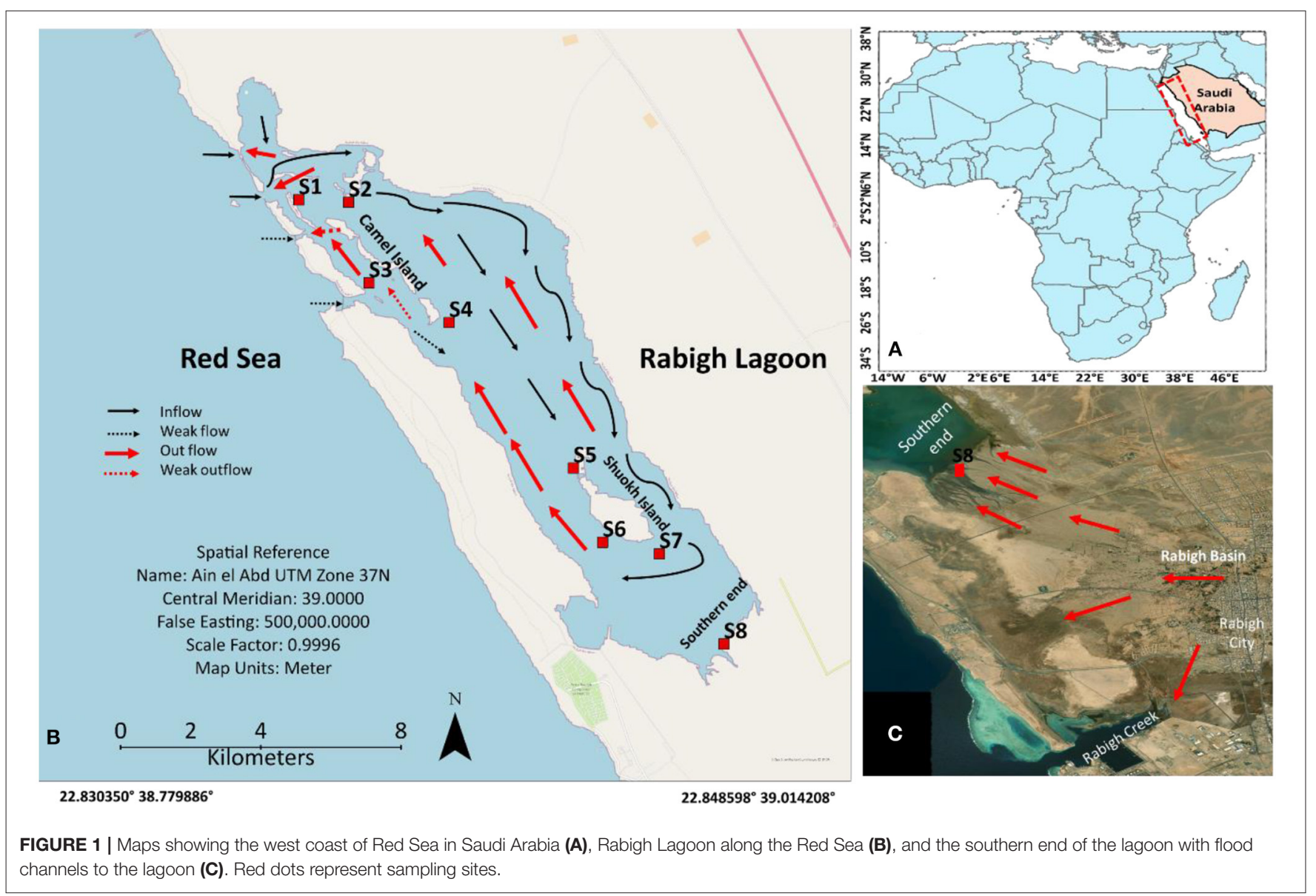


TABLE 1 | Physicochemical properties of seawater and average mangrove height at different sites in Rabigh Lagoon.

\begin{tabular}{|c|c|c|c|c|c|c|c|c|c|}
\hline Sites & Temp. $\left({ }^{\circ} \mathbf{C}\right)$ & Salinity & DO (mg/L) & $\mathrm{pH}$ & MH & CS $(0.063-2 \mathrm{~mm})$ & SSCS $(<0.063 \mathrm{~mm})$ & $\mathrm{G}(>2 \mathrm{~mm})$ & Texture \\
\hline S1 & 24.73 & 39.91 & 6.32 & 8.33 & 4.31 & 84.9 & 14.37 & 0.72 & Sand \\
\hline S2 & 29.32 & 40.15 & 6.32 & 8.35 & 4.14 & 81.2 & 18.13 & 0.66 & Sand \\
\hline S3 & 25.12 & 40.21 & 6.33 & 8.39 & 4.01 & 78.4 & 21.06 & 0.53 & Sand \\
\hline S4 & 24.8 & 40.42 & 6.25 & 8.34 & 3.23 & 71.5 & 28.03 & 0.46 & Sand \\
\hline S5 & 24.98 & 40.66 & 6.24 & 8.32 & 3.12 & 68.6 & 30.97 & 0.42 & Sand \\
\hline S6 & 24.79 & 40.77 & 6.6 & 8.31 & 3.89 & 48.7 & 50.93 & 0.36 & Loamy sand \\
\hline S7 & 26.72 & 42.94 & 5.29 & 8.36 & 3.86 & 46.5 & 53.23 & 0.26 & Loamy sand \\
\hline S8 & 28.82 & 44.86 & 5.15 & 8.49 & 2.61 & 41.3 & 58.67 & 0.02 & Loamy sand \\
\hline Average & $26.16 \pm 0.39$ & $41.24 \pm 0.35$ & $6.06 \pm 0.11$ & $8.36 \pm 0.21$ & $3.65 \pm 0.63$ & $65.14 \pm 6.07$ & $34.86 \pm 4.98$ & $0.43 \pm 0.03$ & \\
\hline
\end{tabular}

DO, Dissolve oxygen; MH, Mangrove height; CS, Coarse sandy; SSCS, Clay and Silt particles; D, Density; G, Gravels.

Rabigh Lagoon. Those sites have distinct temperatures, salinities and dissolved oxygen in the surface water, and nutrient levels in the sediments. We measured antioxidant enzymes such as CAT, GST, and SOD in mangroves, nutrient composition, carbon, and nitrogen isotopes in both mangrove tissues and sediments. Antioxidant enzymes are important biomarkers of oxidative stress in plants (Jithesh et al., 2006; Weintraub et al., 2013; Luo and $\mathrm{Gu}, 2018)$. Contributions of carbon flow from terrestrial and marine environments could be determined using carbon isotope (Bongiorni et al., 2015), while nitrogen isotope ratios can serve as a good indicator of nitrogen sources in aquatic ecosystems (Orlandi et al., 2014; Graniero et al., 2016). Our goal is to demonstrate how nutrients in the sediments, high salinity and temperature interacted to cause stress in mangroves, and shift of the leading factors from the lagoon entrance to the southern end. Our study would help develop a strategy to conserve the fragile lagoon ecosystem.

\section{MATERIALS AND METHODS}

\section{Study Area}

Rabigh Lagoon $\left(22^{\circ} 45^{\prime} \sim 23^{\circ} 00^{\prime} \mathrm{N}, 38^{\circ} 45^{\prime} \sim 39^{\circ} 00^{\prime} \mathrm{E}\right)$ is one of the major lagoons along the west coast of Saudi Arabia (Figure 1). In the northwest, seawater from the Red Sea enters the lagoon through a major inlet, refreshing the lagoon on a daily basis. The tidal ranges are about $20-30 \mathrm{~cm}$, and the depths in the lagoon vary from 1 to $11 \mathrm{~m}$. On average, it takes 15 days for the water to circulate the lagoon, with a flow rate of $50 \mathrm{~cm} \mathrm{~s}^{-1}$ at the entrance and 5 to $20 \mathrm{~cm} \mathrm{~s}^{-1}$ in the center of the lagoon. Sediment textures vary from sandy soil with a higher percentage of coarse grain at the lagoon entrance (S1) to loamy sandy soil predominated by clay silt and silt at S8 (Table 1), with a diversity of seagrass and coral reefs (Youssef and El-Sorogy, 2016; Aljahdali and Alhassan, 2020a).

\section{Measurement of Seawater Physicochemical Parameter}

Depth profiles of seawater temperature, salinity, dissolved oxygen (D.O.) and $\mathrm{pH}$ were measured in-situ using a YSI 556 MPS multi-parameter meter at different sites in the lagoon. Density is calculated from temperature and salinity following a method described in Zhang et al. (2016).

\section{Sample Collection}

Mangrove tissues and sediments were collected from coral reefs at the entrance of Red Sea water (S1), close to the entrance (S2), Camel Island (S3 and S4), Shuokh Island (S5, S6, and S7), and the southern end of the lagoon (S8) (Figure 1). For each site, matured leaves, stems and roots from $15 \mathrm{~A}$. marina mangrove trees and corresponding surface sediment $(0-20 \mathrm{~cm})$ were collected and stored in polythene bags inside an iced container before taking back to the laboratory.

\section{Analyses of Phosphorus in Plants and Sediments}

Plant leaves, branches and sediments were dried in an oven at $40^{\circ} \mathrm{C}$ for $48 \mathrm{~h}$. They were then ground into powder using mortar and pestle, and sieved through a $53 \mu \mathrm{m}$ sieve. $0.2 \mathrm{~g}$ of dried plant tissue was digested in a mixture of $\mathrm{HNO}_{3}$ and $\mathrm{H}_{2} \mathrm{O}_{2}$ (3:1) at $180^{\circ} \mathrm{C}$ for $45 \mathrm{~min}$. $0.4 \mathrm{~g}$ of dried sediments was loaded into a $50 \mathrm{ml}$ digestion vessel, and $8 \mathrm{ml}$ of $\mathrm{HNO}_{3}: \mathrm{HCl}(1: 1)$ was added. The vessel was placed inside an Anton-Paar PE Multiwave 3000 microwave oven and digested at $200^{\circ} \mathrm{C}$ for about $1 \mathrm{~h}$ (United States Environmental Protection Agency., 1997; Bakshi et al., 2018). Ultrapure Millipore Q water was then added to fill the vessel and placed on a shaker for $24 \mathrm{~h}$. The solution was filtered through a GF/F filter (Whatman) and the filtrate was subsequently analyzed for phosphorus content on a Varian 720ES inductively coupled plasma-optical emission spectrometer.

\section{Measurement of Total Organic Matter and Nitrogen in Leaves and Sediments}

$2 \mathrm{mg}$ of grounded leaves were weighed into a tin capsule and analyzed on FLASH 2000 CHNS analyzer for total carbon and nitrogen, following a protocol described by Zimmermann et al. (1997). Concentrations of carbon and nitrogen in sediments were analyzed following the $\mathrm{K}_{2} \mathrm{Cr}_{2} \mathrm{O}_{7} / \mathrm{H}_{2} \mathrm{SO}_{4}$ oxidation method and Semimicro-Kjeldahl protocol, respectively (Yeomans and Bremner, 1991). 


\section{Grain Size Analyses}

Oven-dried sediment samples were weighed, washed gently and disaggregated by passing it consequently through $0.063 \mathrm{~mm}$ and $2 \mathrm{~mm}$ sieves with running water to facilitate breaking up of clumps. The fractions of gravel $(>2 \mathrm{~mm})$, coarse grain $(0.063 \sim 2 \mathrm{~mm}$ ), and mud (clay and silt, $<0.063 \mathrm{~mm}$ ) were dried and weighed to determine percentages in each fraction.

\section{Carbon and Nitrogen Isotope Analyses}

Dried sediment samples were treated with $10 \% \mathrm{HCl}(\mathrm{v} / \mathrm{v})$ to remove carbonate and then rinsed with ultrapure Millipore $\mathrm{Q}$ water till $\mathrm{pH}$ reached 7 . They were then dried in an oven at $50^{\circ} \mathrm{C}$ and ground. Dried leave samples were ground and homogenized, and then directly analyzed. Bulk organic matter $\delta^{13} \mathrm{C}$ and $\delta^{15} \mathrm{~N}$ were measured on a Thermo elementary analyzer-ConFlo IV-Delta V Advantage mass spectrometer in Ocean College, Zhejiang University, following a protocol described in Gong and Zhang (2015). All $\delta^{13} \mathrm{C}$ and $\delta^{15} \mathrm{~N}$ results were reported to V-PDB and air- $\mathrm{N}_{2}$, respectively. The standard deviation is $<0.2 \%$.

\section{Assay of Antioxidant Enzymes in Avicennia marina}

Leaves were cleaned with distilled water to remove debris and then pulverized in an ice-cold mortar and pestle with $0.01(\mathrm{M})$ phosphate buffer ( $\mathrm{pH}$ 7), followed by centrifugation at 14,000 rpm and $4^{\circ} \mathrm{C}$ for $24 \mathrm{~min}$ (Kumar et al., 2016; Bakshi et al., 2018; Aljahdali and Alhassan, 2020a,b). The supernatant was analyzed for antioxidant activities on a Labtronics spectrophotometer (Model: LT-291 Single Beam UV-VIS).

For assay of CAT activity, the reaction mixtures contained $0.01 \mathrm{M}$ phosphate buffer, $30 \mathrm{mM}$ hydrogen peroxide, and the enzyme extract. It was measured in absorbance at $230 \mathrm{~nm}$ for $2 \mathrm{~min}$., in $\mu \mathrm{mol} / \mathrm{min} / \mathrm{mg}$ protein.

The reaction mixture for assay of GST activity was composed of $1 \mathrm{mM}$ 1-chloro 2,4-dinitrobenzene (CDNB), $0.1 \mathrm{M}$ potassium phosphate buffer at $\mathrm{pH} 6.5,1 \mathrm{mM} \sim 40 \mathrm{mM}$ GSH, $100 \mu \mathrm{L}$ of leaf extracts in a total volume of $1 \mathrm{~mL}$. After the production of Glutathione S- dinitrobenzene (GS-DNB), GST activity was measured on a Labtronics spectrophotometer at $340 \mathrm{~nm}$ per min at $25^{\circ} \mathrm{C}$ (Habig et al., 1974).

The assay of SOD in A. marina followed a protocol described by Keyster et al. (2012). An aliquot $(10 \mu \mathrm{l})$ of the supernatant was added to a solution containing $0.1 \mathrm{mM}$ xanthine, $6.25 \mathrm{nM}$ xanthine oxidase, $50 \mathrm{mM} \mathrm{K}_{2} \mathrm{HPO}_{4}, \mathrm{pH} 7.8,0.1 \mathrm{mM}$ EDTA, $0.025 \%$ (w/v) Triton X-100, 0.1 mM 2-(4-iodophenyl)-3(4-nitrophenyl)-5-(2,4-disulfophenyl)-2H-tetrazolium (WST-1), and measured on a Labtronics spectrophotometer at absorption at $450 \mathrm{~nm}$ at $37^{\circ} \mathrm{C}$ for $20 \mathrm{~min}$. The specific activity was recorded as units/mg protein, where $1 \mathrm{U}$ of enzyme activity = enzyme concentration required to avoid $50 \%$ production of chromogen under conditions of the assay for $1 \mathrm{~min}$.

\section{Data Analyses}

The variations in nutrient concentrations in A. marina leaves, branches, sediment, and antioxidative responses in A. marina leaves were analyzed. At 95\% confidence interval, one-way analysis of variance (ANOVA) was performed to assess variation in sites in terms of nutrient concentrations and stable isotopes in A. marina and sediments. Where there is a significant difference in concentrations, Tukey's HSD test was used to separate the means. The $t$-test was used to identify differences in $\delta^{13} \mathrm{C}$ and $\delta^{15} \mathrm{~N}$ in mangroves and sediments. Principal component analysis (PCA) was used to determine the relationship and contribution to variations among nutrients, $\mathrm{C} / \mathrm{N}, \mathrm{N} / \mathrm{P}$, carbon and nitrogen isotope ratios, sediment grain size, physicochemical parameters, and antioxidants in mangrove leaves. Before data analysis, Shapiro-Wilk test was applied to check if the data were normally distributed. Multivariate item analysis (MIA) was applied to determine correlation among nutrients in A. marina and antioxidant enzymes. All analyses were carried out using $\mathrm{R}$ for Windows (v. 4.0.3), IBM SPSS v.22, and Minitab v.17.

\section{RESULTS}

\section{Increasing Salinity and Temperature, and Percentage of Mud Along the Inflow Route}

Salinities in Rabigh Lagoon increased rapidly from 39.9 at the lagoon mouth (S1) along the inflow route to 42.9 at Shuokh Island (S7), and 44.9 at the southern end (S8) (Table 1), while little changes were observed from S2 to S6. Sea surface temperatures also increased from $24.3^{\circ} \mathrm{C}$ at $\mathrm{S} 1$ to $26.7^{\circ} \mathrm{C}$ at $\mathrm{S} 7$ and $28.8^{\circ} \mathrm{C}$ at S8. D.O. gradually decreased from $6.3 \mathrm{mg} / \mathrm{L}$ at the entrance (S1) to $5.3 \mathrm{mg} / \mathrm{L}$ at Shuokh Island (S7) and $5.12 \mathrm{mg} / \mathrm{L}$ at the southern end of the lagoon. $\mathrm{pH}$ increased gradually from 8.33 at $\mathrm{S} 1$ to 8.36 at $\mathrm{S} 7$ and 8.49 at the southern end of the lagoon (Table 1).

The percentage of coarse grain $(0.063 \sim 2 \mathrm{~mm})$ in sediments decreased from $84.9 \%$ at S1 to $41.3 \%$ at S8, while clay silt particles increased from $14.37 \%$ at S1 to $58.67 \%$ S8 (Table 1). As a result, the texture of sediment was predominantly sandy at the entrance of the lagoon, and loamy at $S 8$, which was due to clay materials brought by runoff and low rate of flow.

\section{Nutrients in Sediment and Mangrove Tissues}

Generally speaking, \%OC, \% TP, and \% TN in the sediments at S1 were much higher than those from S2 to S6, then increased slightly at S7, and became significantly higher at S8 (Table 2). They were substantially smaller than those in mangrove tissues (Table 2). \%TN in the leaves was significantly higher than those in branches (Tukey's HSD; $p<0.05$; Table 2), but there were no differences in \%TP between them (Table 2). \%TN in leaves at S8 was about 2.5 times higher than that at S1, very close to the ratio of \%TN in the sediments at S8 vs. \%TN at Site 1 (Table 2). However, \% TP in leaves at S8 was about 13 times higher than that at S1, substantially higher than the ratio of 4 in the sediments (Table 2), suggesting a higher enrichment factor of $\mathrm{P}$ in leaves than $\mathrm{N}$.

The principal component analysis with sediment grain size, $\mathrm{C} / \mathrm{N}$ ratio, $\mathrm{N} / \mathrm{P}$ ratio, stable isotope, and nutrients revealed the relationship between sediment grain size and nutrients, with a total variation of $85.3 \%$ contributed by components 1 (66.5\%) and $2(18.8 \%)$ (Figures 2A, 3A). Site contribution to the total 


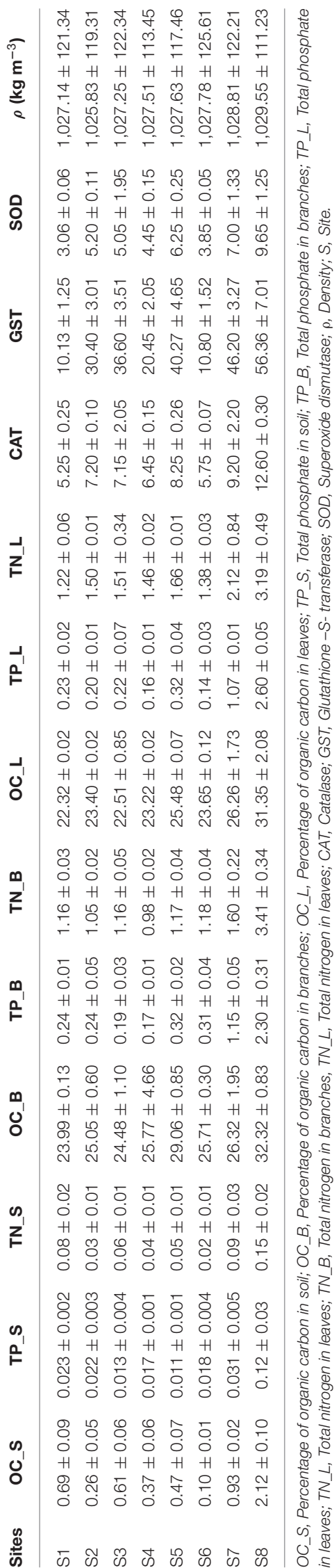

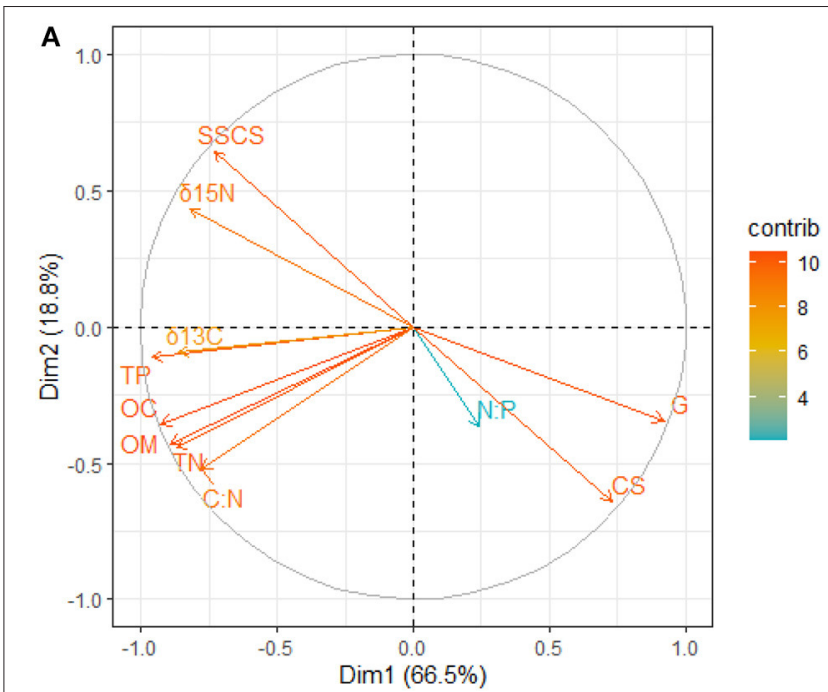

B

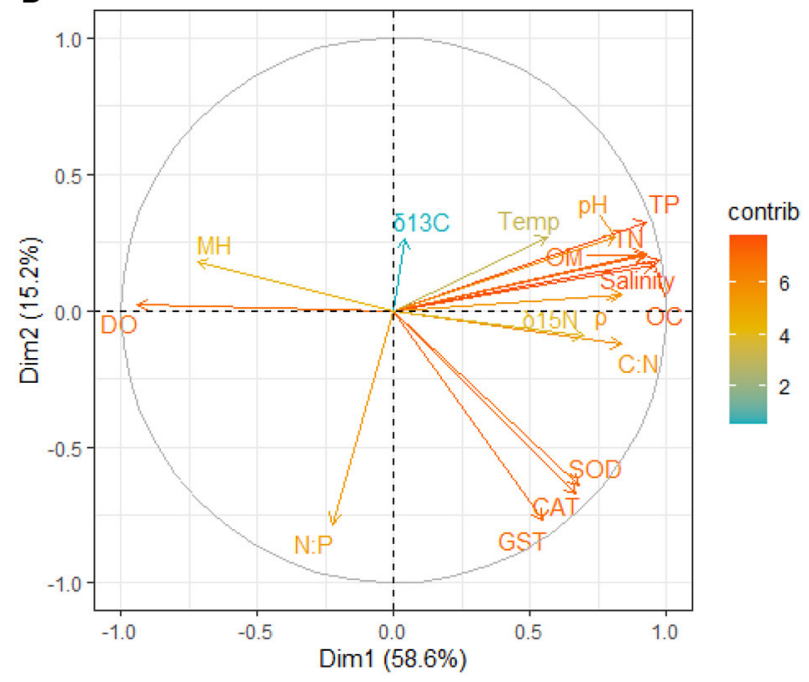

FIGURE 2 | Principal component analysis contribution plot for the relationship between (A) sediment grain size and nutrients (B) nutrients, physicochemical parameters, antioxidants, and mangrove height. OC, Percentage of organic carbon; TN, Total nitrate; TP, Total phosphate; C:N, Carbon-Nitrogen ratio; $\mathrm{N}: \mathrm{P}$, Nitrogen-Phosphorus ratio; $\delta^{13} \mathrm{C}$, Carbon isotope; $\delta^{15} \mathrm{~N}$, Nitrogen isotope; CS, Coarse sandy; SSCS, Clay and Silt particles; G, Gravels; CAT, Catalase; GST, Glutathione-S-transferase; SOD, Superoxide dismutase; $\rho$, Density; DO, Dissolve oxygen; Temp, Temperature; MH, Mangrove height.

variation was highest at S8 (Figure 4A). Clay and silt percentages have a big impact on $\mathrm{C} / \mathrm{N}$, nutrients and $\delta^{15} \mathrm{~N}$ in the sediments, while coarse fractions in sediments influence N/P (Figures 2A, $3 \mathrm{~A})$. Site $\mathrm{S} 8$ has the highest $\mathrm{N}$ and $\mathrm{P}$ concentrations in sediments, branches and leaves (Table 2), and highest $\mathrm{C} / \mathrm{N}$ ratio (15.28) and lowest N/P ratio (1.03) in sediments, and the lowest $\mathrm{C} / \mathrm{N}$ and N/P ratio for mangrove tissues (Table 3 ).

\section{Antioxidant Enzyme Activities in Avicennia marina}

Among all sites in Rabigh Lagoon, mangroves at S1 at the lagoon entrance had the lowest CAT (5.25 $\mu \mathrm{mol} / \mathrm{mg}$ protein), 

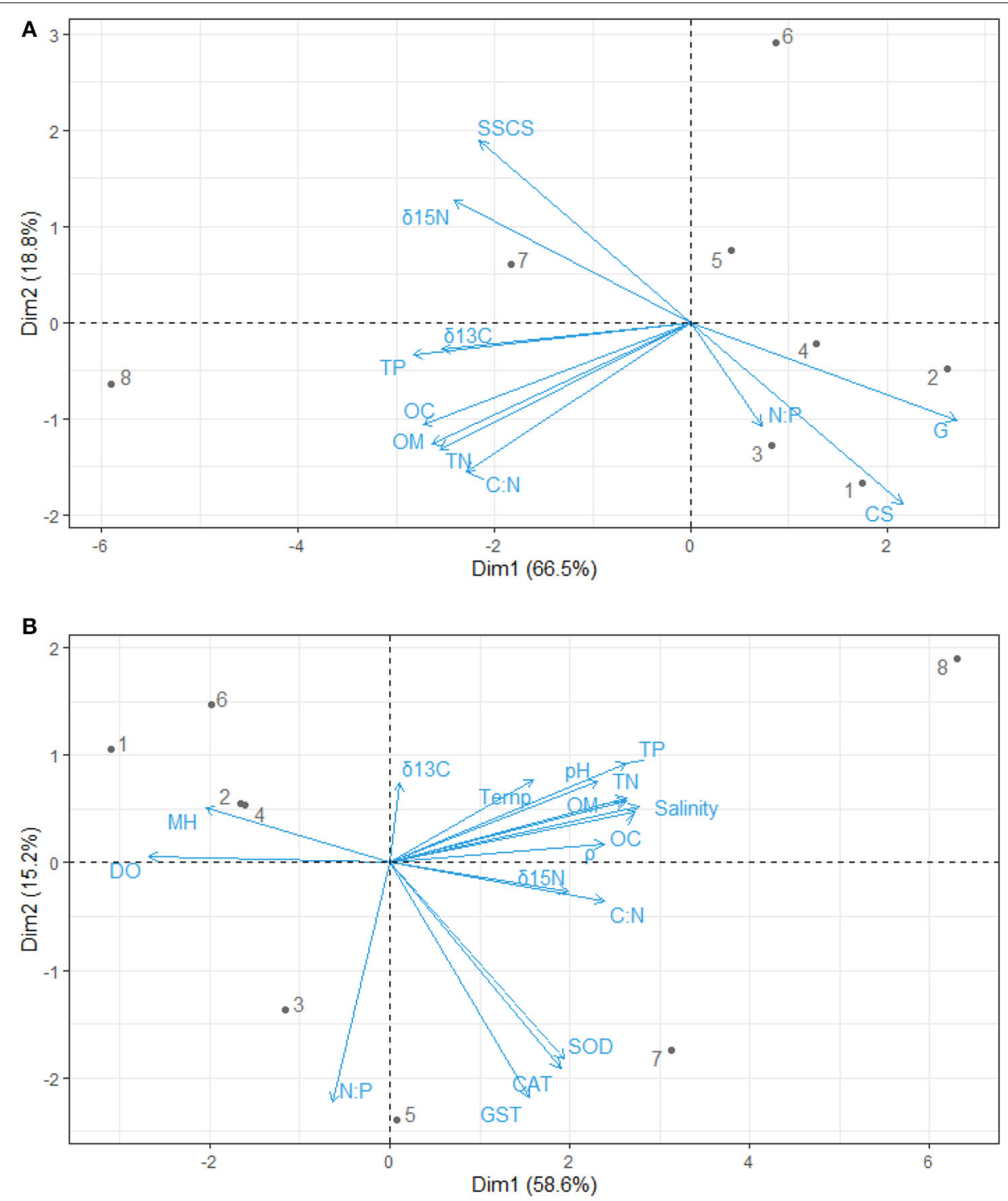

FIGURE 3 | Principal component analysis biplot for the relationship between (A) sediment grain size and nutrients (B) nutrients, physicochemical parameters, antioxidants, and mangrove height. OC, Percentage of organic carbon; TN, Total nitrate; TP, Total phosphate; C:N, Carbon-Nitrogen ratio; N:P, Nitrogen-Phosphorus ratio; $\delta^{13} \mathrm{C}$, Carbon isotope; $\delta^{15} \mathrm{~N}$, Nitrogen isotope; CS, Coarse sandy; SSCS, Clay and Silt particles; G, Gravels; CAT, Catalase; GST, Glutathione-S-transferase; SOD, Superoxide dismutase; $\rho$, Density; DO, Dissolve oxygen; Temp, Temperature; MH, Mangrove height.

GST (10.13 $\mu \mathrm{mol} / \mathrm{mg}$ protein) and SOD (3.06 $\mu \mathrm{mol} / \mathrm{mg}$ protein), while mangroves in the southern end of the lagoon, S8, had the highest CAT $(12.60 \mu \mathrm{mol} / \mathrm{mg}$ protein), GST $(53.36 \mu \mathrm{mol} / \mathrm{mg}$ protein), and $\operatorname{SOD}(9.65 \mu \mathrm{mol} / \mathrm{min} / \mathrm{mg}$ protein) (Table 2$)$. Multivariate item analysis (MIA) of the correlation among organic carbon, total nitrogen and total phosphate in leaves of $A$. marina and antioxidant enzymes (Figure 5) showed that organic carbon, total nitrogen and total phosphate in A. marina leaves and antioxidant enzyme activities were correlated significantly $(p<0.0001)$. There was also a negative relationship between the antioxidants (CAT, GST and SOD), salinity and mangrove height $(r=-0.7203)$ and dissolve oxygen $(r=-0.9396)$ (Figures 2B, 3B). Site contribution was highest at S8 (Figure 4B).
Salinity, followed by nutrients, and temperature in order, are most important factors contributing to the total variations at Site S8, and they had a negative relationship with mangrove height and DO (Figures 2B, 3B, 4B).

\section{Carbon and Nitrogen Isotope in Mangrove Tissues and Sediments}

$\delta^{13} \mathrm{C}$ values of mangrove leaves and branches ranged from $-27.35 \sim-25.80 \%$ o, and $-26.89 \sim-24.06 \%$, respectively (Table 3), indicating no significant difference among mangrove tissues. The lowest $\delta^{13} \mathrm{C}$ values of leaves and branches occurred at $\mathrm{S} 1$ while highest at S8 (Table 3). The $\delta^{13} \mathrm{C}$ values in sediments were substantially higher than those in mangroves (Table 3), and 

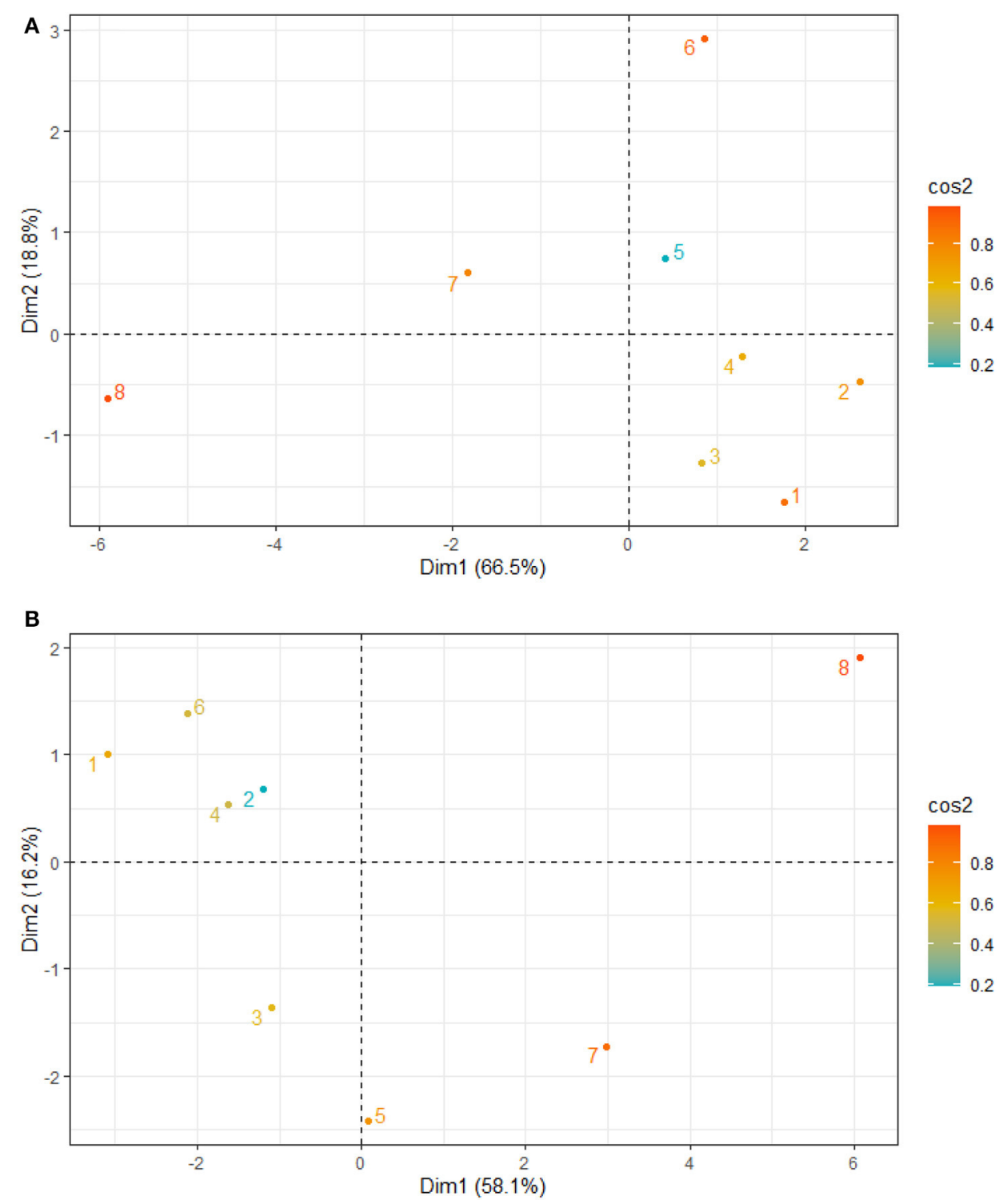

FIGURE 4 | Principal component analysis site contribution to total variation and grouping of Sites 1-8 for the relationship between (A) sediment grain size and nutrients (B) nutrients, physicochemical parameters, antioxidants, and mangrove height.

TABLE 3 | Stable isotopes, C:N and N:P in sediment and mangrove A. marina.

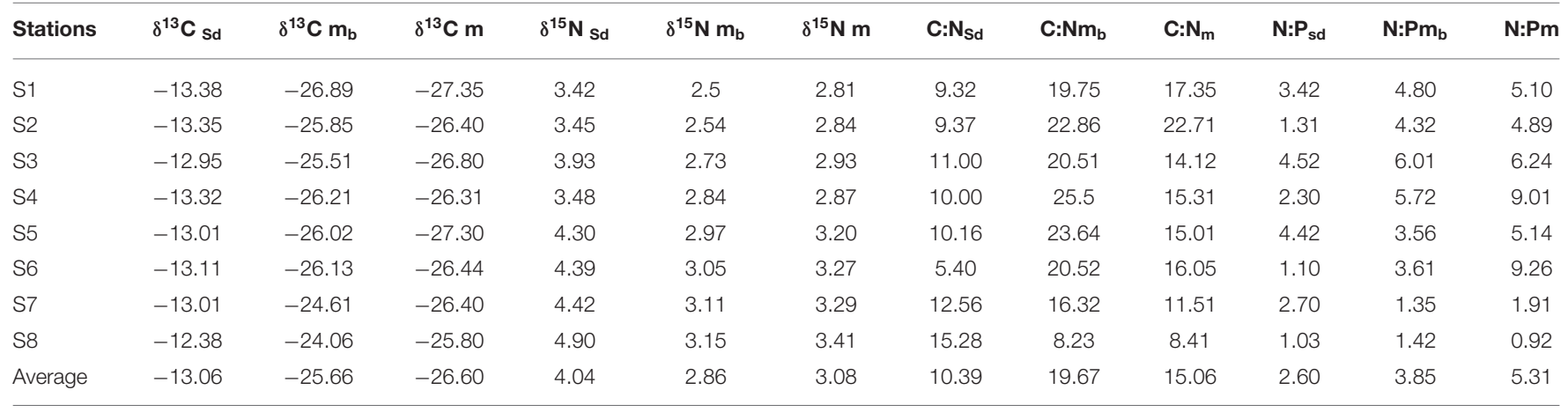

Sd, Sediment; mb, Mangrove branches; $m$, Mangrove leaves; C:N, Carbon-Nitrogen ratio; N:P, Nitrogen-Phosphorus ratio. 


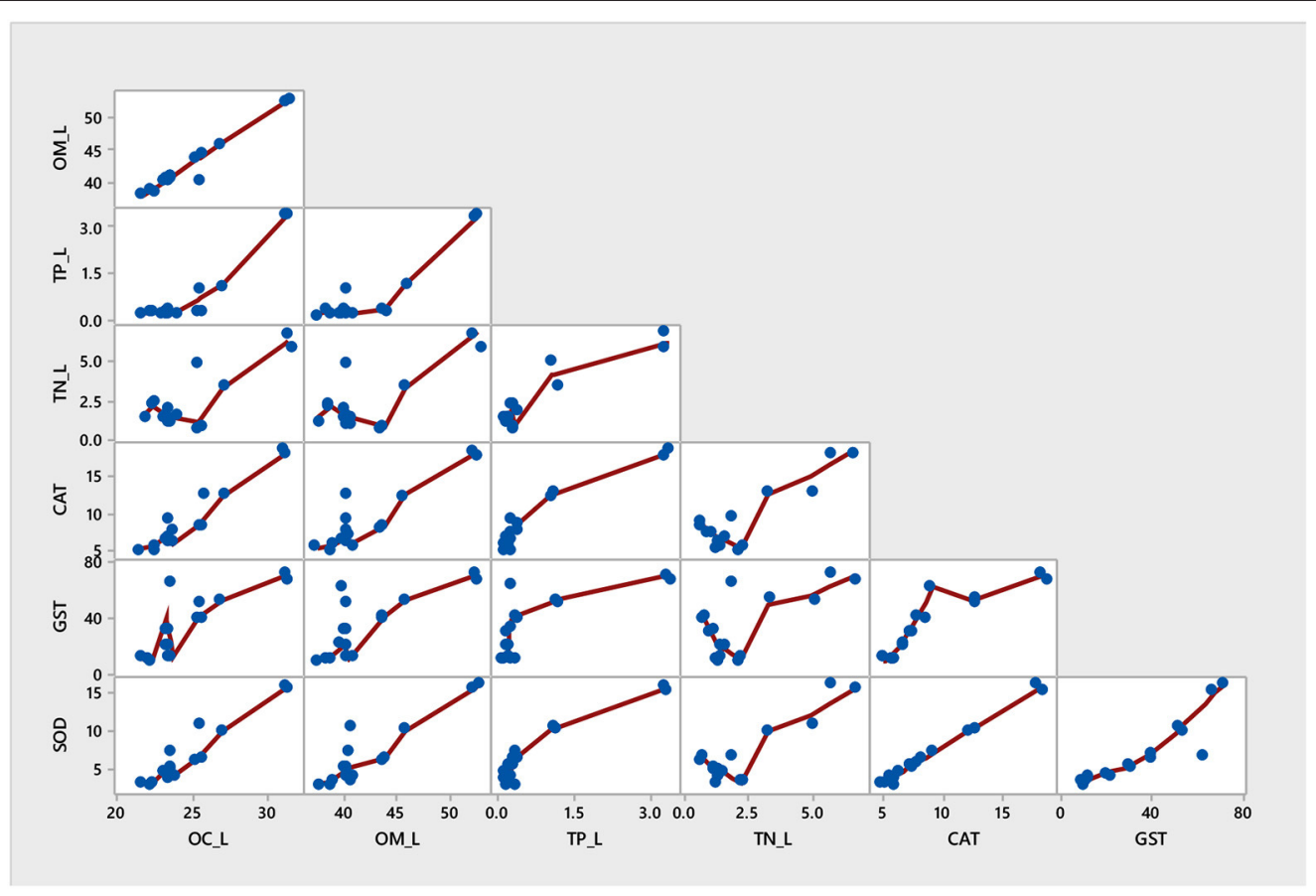

FIGURE 5 | Multivariate item analysis (MIA) for antioxidant enzymes activities and nutrients in mangrove $A$. marina.

increased from $-13.38 \%$ at S1 to $-12.38 \%$ at S8 (Table 3). $\delta^{15} \mathrm{~N}$ values of mangrove leaves ranged from $2.81 \%$ at $\mathrm{S} 1$ to 3.41 $\%$ at S8 (Table 3). $\delta^{15} \mathrm{~N}$ of branches showed the same pattern (Table 3). Sediment $\delta^{15} \mathrm{~N}$ values increased from $3.42 \%$ at $\mathrm{S} 1$ to $4.90 \%$ at the southern end of the lagoon (S8), and all are higher than those in mangrove branches $(2.86 \pm 0.75 \%$ o $)$ and leaves $(3.08$ $\pm 0.89 \%$ o).

$\delta^{13} \mathrm{C}$ values in the sediments were positively correlated with $\mathrm{C} / \mathrm{N}$ ratios $(r=0.7221)$, organic carbon contents $(r=$ $0.8547)$, total nitrogen contents $(r=0.8136)$ and total phosphate contents (0.8452) (Figures 2A, 3A). Similarly, $\delta^{15} \mathrm{~N}$ values in the sediments had a positive correlation with $\mathrm{C} / \mathrm{N}(r=0.7899)$ (Figures 2A, 3A). $\delta^{13} \mathrm{C}$ and $\delta^{15} \mathrm{~N}$ values were also affected by dissolved oxygen and mangrove height (Figures 2B, 3B), especially at the southern end (S8) (Figure 2). Moreover, there was a negative correlation between N/P $(r=-0.2215)$ with $\delta^{13} \mathrm{C}$ and $\delta^{15} \mathrm{~N}$ (Figures 2B, 3B).

\section{DISCUSSION}

\section{Restricted Circulation to the Southern End of the Lagoon}

It takes 15 days on average for water to circulate the lagoon and the inflow rate is typically at $50 \mathrm{~cm} \mathrm{~s}^{-1}$ (Aljahdali et al., 2021). Strong evaporation led to an abrupt increase in salinity and temperature from S1 to S8 (Table 1). As a result surface seawater density increased gradually from $1,027.14 \mathrm{~kg} \mathrm{~m}^{-3}$ at $\mathrm{S} 1$ and $1,025.83 \mathrm{~kg} \mathrm{~m}^{-3}$ at S2 to $1,028.81 \mathrm{~kg} \mathrm{~m}^{-3}$ at S7 and
$1,029.55 \mathrm{~kg} \mathrm{~m}^{-3}$ at the southern end of the lagoon (S8). Thus, a large portion of inflow seawater sinks and becomes subsurface outflow, and only a small portion of Red Sea water could reach Site 8. The restricted circulation contributed to low D.O at S8 due to low solubility in warmer water and stagnant water body (Saravanakumar et al., 2008), and predominance of clay and silt in texture (Table $\mathbf{1}$ ).

\section{Distribution of Nutrients in Rabigh Lagoon}

The significant variations in \% TN and \% TP in the sediments are most likely due to restricted circulation inside the lagoon, sediment texture, land runoff input, and camel grazing. The most striking feature was the substantial enrichment of $\mathrm{N}$ and $\mathrm{P}$ at the southern end (S8).

High nitrogen, phosphorus and organic carbon in the sediments at Site S8 (Table 1) could be attributed to the predominance by clay and silt, as clay particles have a high capacity of absorption of nutrients in form of organic molecules (Naidu et al., 1982), and the stagnant status of water body favorable for organic matter preservation. Additional potential contribution might be from runoff entering the Rabigh Lagoon at S8 due to seasonal flood events (Zaigham et al., 2017). The runoff has two important catchments, Rabigh City and Wadi Rabigh, and there are agricultural activities around their drainage distributaries (Figure 1B). In addition, camel grazing is more prevalent at site S8 due to easy access, and their fecal pellets consequently increase both $\mathrm{N}$ and $\mathrm{P}$ in the sediments, as 
reported in a southern Australian lagoon mangrove ecosystem (Reef et al., 2014).

The $\delta^{15} \mathrm{~N}$ values at site $\mathrm{S} 8$ are substantially higher than those reported in A. marina in Australia (1.6 2.2\%o) (Costanzo et al., 2005), most likely due to anthropogenic influences. Agricultural waste could cause an increase in $\delta^{15} \mathrm{~N}$ signatures in mangrove ecosystems (Zulkifli et al., 2016; Khan et al., 2017, 2019). For example, $\delta^{15} \mathrm{~N}$ values of mangroves in New Zealand reached (5.4 9.8\%o) (Gritcan et al., 2016), and those in Matang mangrove reserve in Malaysia were as high as $8.67 \%$ o because of disposed polluted water by industrial zone close to the study area (Khan et al., 2017).

\section{Different Factors for Stress in Mangroves Across Rabigh Lagoon}

Antioxidants such as CAT, GST and SOD can scavenge reactive oxygen species such as $\mathrm{H}_{2} \mathrm{O}_{2}, \mathrm{OH}, \mathrm{O}_{2}$, etc. produced by organisms under stress (Shahid et al., 2014; Li et al., 2018; Asaeda and Barnuevo, 2019). Therefore, they can serve as biomarkers and early signals for physiological responses of $A$. marina to stress (Tausz et al., 2004; Jithesh et al., 2006; Caregnato et al., 2008; Aljahdali and Alhassan, 2020a,c). A negative correlation between antioxidants and mangrove height $(r=-0.7203)$ is a result of the response of antioxidants to stress in mangroves (Farzana et al., 2019). High salinity or low nutrient could affect mangrove height and cause an increase in antioxidants activities (Das et al., 2016).

There were significant variations in CAT, GST and SOD in mangroves across from lagoon entrance to the southern end, with the highest average values at sites S6, S7, and S8. A positive correlation between \%OC, \% TN, and \% TP and the three enzymes (Figure 3) indicates that low nutrient most likely led to stress in mangroves at Rabigh Lagoon (Wojdyło et al., 2007; Radušien et al., 2019; Aljahdali and Alhassan, 2020b). Our previous study (Aljahdali and Alhassan, 2020a) at Rabigh lagoon showed weak positive correlations between Zn (CAT: $r=0.202$, GST: $r=$ 0.341, and SOD: $r=0.210$ ), Cr (CAT: $r=0.276$, GST: $r=$ 0.158 and SOD: $r=0.279$ ) and Cd (CAT: $r=0.090$, GST: $r=$ 0.096 and SOD: $r=0.097$ ) with antioxidant enzymes activity. In contrast, stronger positive correlations were recorded in this study between salinity (CAT: $r=0.9784$, GST: $r=0.9718$, and SOD: $r=0.9781$ ), nutrients; \%TN (CAT: $r=0.9878$, GST: $r$ $=0.9678$ and SOD: $r=0.9871$ ), and \%TP (CAT: $r=0.9776$, GST: $r=0.9754$, and SOD: $r=0.9788$ ) and antioxidant enzymes activity. This gives an insight into possible higher contribution to stress by salinity and nutrient limitation than other stressors such as metals that were determined in the same study area previously. In another ex-situ experimental setup, CAT, SOD and peroxidase activities were stimulated in Excoecaria agallocha, a species of mangrove, as the concentrations of salinity increase from 5 to 25 psu under excess nutrient addition (Chen and Ye, 2014).

Khan et al. (2019) found out that mangrove A. marina possessing the highest biomass, density, and height $(12.9 \mathrm{~m})$ in Matang Mangrove Forest Reserve, Malaysia, had very high \%N
(12.01\%) and \% $(0.276 \%)$. In the oligotrophic central Red Sea, however, \%TN and \%TP in the stunted mangrove trees of $A$. marina leaves were only $0.84 \sim 2.89 \%$, and $0.007 \sim 0.12 \%$, respectively (Garcias-Bonet et al., 2019). \%TN and \% TP in the sediments were 0.025 to $0.639 \%$, and 0.014 to $0.098 \%$ (GarciasBonet et al., 2019). In Rabigh Lagoon, \%TN and \%TP in $A$. marina leaves from S1 to S7 ranged from $1.22 \sim 2.12 \%$ to $0.14 \sim$ $1.07 \%$. On the other hand, $\mathrm{N}$ and $\mathrm{P}$ in the sediments from S1 to S7 ranged from 0.02 to $0.09 \%$ and 0.01 to $0.03 \%$, respectively (Table 2). It is worth pointing out that though \% TN in leaves under stress was only about $1 / 10$ of that in healthy mangrove leaves in Malaysia, \%TP in mangrove leaves under stress or healthy conditions were close. Such phenomenon indicates that $\mathrm{N}$ limitation was the main cause for stress in mangroves from S1 to S7. On the other hand, they were better off compared to those in the oligotrophic central Red Sea.

S8 has significantly higher $\mathrm{N}$ and $\mathrm{P}$ in both leaves and sediments. \% TN and \% TP in A. marina leaves at S8 were 3.2 and $2.6 \%$, respectively (Table 2 ). \%TN and \% $\mathrm{TP}$ in the sediments at S8 were $0.15 \%$ and $0.12 \%$, respectively (Table 2 ). $\% \mathrm{TN}$ in leaves at S8 was about $1 / 4$ of that in healthy leaves in Malaysia. In our case, \% TP in leaves at S8 was much higher than those in Sites $\mathrm{S} 1$ to $\mathrm{S} 7$, suggesting that $\mathrm{N}$ limitation is no longer the main cause for the biggest stress in mangroves at S8. S8 is distinct from the rest sites as it features high salinity, high temperature and low D.O. in surface water, and high $\mathrm{N}$ and $\mathrm{P}$ in the sediments. Lowest D.O. at site S8 in Rabigh Lagoon coincided with the lowest average mangrove height, suggesting that low D.O. in mangrove ecosystem exacerbates degradation or stress in mangroves (Prasad, 2012).

The negative correlation between mangrove height and salinity, and temperature $(r=-0.7203)$ might be due to the fact that high salinity results in decreased nitrogen accumulation and inhibition of potassium uptake (Chen and Ye, 2014) and thus incur oxidative stress in mangroves (Takemura et al., 2000). While $\delta^{13} \mathrm{C}$ of sediment at S8 was higher than that at $\mathrm{S} 1$ by $1 \%, \delta^{13} \mathrm{C}$ of leaves in $A$. marina at S8 was $2.8 \%$ heavier than that at S1 (Table 3). The extra enrichment of ${ }^{13} \mathrm{C}$ in A. marina was most likely due to stress by extremely high salinity, 44.86 (Table 1). A previous study showed that an increase in salinity from 13 to 24 caused a dramatic increase in $\delta^{13} \mathrm{C}$ values from -33.81 to $-28.41 \%$ in Matang mangrove forest reserve, Malaysia (Khan et al., 2017). Stress has indirect consequence of reduced stomatal conductance, resulting in decrease intercellular $\mathrm{CO}_{2}$ pressure. Since ${ }^{12} \mathrm{C}$ is preferentially assimilated due to discrimination during diffusion and decarboxylation, the reduced $\mathrm{CO}_{2}$ pressure causes ${ }^{13} \mathrm{C}$ enrichment in the assimilated material (van Groenigen and van Kessel, 2002).

Extreme high temperatures constitute another type of abiotic stress in mangrove stands, as they can affect mangroves' developmental, physiological and biochemical integrity (Vuleta et al., 2015). When mangroves were exposed to elevated temperatures above ambient $\left(>25^{\circ} \mathrm{C}\right)$, leaf abscission, 
shoot growth inhibition, fruit damage have been reported (Bita and Gerats, 2013).

\section{CONCLUSION}

Rabigh Lagoon is characterized by seawater exchange with the Red Sea through an open inlet, but strong evaporation led to the rapid increase in salinity and temperature along the inflow route. Surface water sinks to become subsurface outflow, before reaching the southern end. Restricted circulation resulted in large salinity, temperature, nitrogen, and phosphorus abundance gradients from the northern entrance to the southern end in the lagoon.

Nitrogen limitation in Rabigh Lagoon from S1 to S7 are the main causes for stress in mangroves, but is better off compared to oligotrophic central Red Sea. The higher concentrations of $\mathrm{N}$ and $\delta^{15} \mathrm{~N}$ value at the southern end were due to stagnant water, runoff bringing agriculture fertilizer from catchments during seasonal flooding events, and frequent camel grazing. At the southern end, the extra enrichment in $\delta^{13} \mathrm{C}$ in leaves relative to that in the sediment was caused by stress due to extremely high salinity. As a result, high salinity is the predominant factor for the biggest stress inside the lagoon. Our work would be helpful to develop a strategy to preserve fragile ecosystem in lagoons along the Red Sea when global warming strengthens increasing salinities in lagoons.

\section{REFERENCES}

Aljahdali, M. O., and Alhassan, A. B. (2020a). Metallic pollution and the use of antioxidant enzymes as biomarkers in bellamya unicolor (Olivier, 1804) (Gastropoda: Bellamyinae). Water 12:202. doi: 10.3390/w12010202

Aljahdali, M. O., and Alhassan, A. B. (2020b). Spatial variation of metallic contamination and its ecological risk in sediment and freshwater mollusk: Melanoides tuberculata (Müller, 1774) (Gastropoda: Thiaridae). Water 12:206. doi: $10.3390 /$ w12010206

Aljahdali, M. O., and Alhassan, A. B. (2020c). Ecological risk assessment of heavy metal contamination in mangrove habitats, using biochemical markers and pollution indices: A case study of Avicennia marina L. in the Rabigh lagoon, red sea. Saudi J. Biol. Sci. 27, 1174-1184. doi: 10.1016/j.sjbs.2020.02.004

Aljahdali, M. O., Munawar, S., and Khan, W. R. (2021). Monitoring mangrove forest degradation and regeneration: landsat time series analysis of moisture and vegetation indices at Rabigh Lagoon, red sea. Forests 12:52. doi: 10.3390/f12010052

Almahasheer, H., Duarte, C. M., and Irigoien, X. (2016). Nutrient limitation in central Red Sea mangroves. Front. Mar. Sci. 3:271. doi: $10.3389 /$ fmars.2016.00271

Almahasheer, H., Serrano, O., Duarte, C. M., Arias-Ortiz, A., Masque, P., and Irigoien, X. (2017). Low carbon sink capacity of Red sea mangroves. Sci. Rep. 7:9700. doi: 10.1038/s41598-017-10424-9

Alongi, D. (2011). Early growth responses of mangroves to different rates of nitrogen and phosphorus supply. J. Exp. Mar. Biol. Ecol. 397, 85-93. doi: 10.1016/j.jembe.2010.11.021

Andrews, S. S., Karlen, D. L., and Cambardella, C. A. (2004). The soil management assessment framework: a quantitative soil quality evaluation method. Soil. Sci. Soc. Am. J. 68, 1945-1962. doi: 10.2136/sssaj2004.1945

Asaeda, T., and Barnuevo, A. (2019). Oxidative stress as an indicator of nichewidth preference of mangrove Rhizophora stylosa. Forest. Ecol. Manag. 432, 73-82. doi: 10.1016/j.foreco.2018.09.015

\section{DATA AVAILABILITY STATEMENT}

The raw data supporting the conclusions of this article will be made available by the authors, without undue reservation.

\section{AUTHOR CONTRIBUTIONS}

MA and ZZ designed the study. MA, AA, and ZZ performed the field surveys, laboratory analysis, contributed to the initial and final drafting of the manuscript, improvement, and approval for submission. AA performed statistical analyses. All authors contributed to the article and approved the submitted version.

\section{FUNDING}

This project was funded by the National Plan for Science, Technology, and Innovation (MAARIFAH), King Abdulaziz City for Science and Technology, the Kingdom of Saudi Arabia, award number (14-ENV263-03).

\section{ACKNOWLEDGMENTS}

The authors acknowledge with thanks the Science and Technology Unit, King Abdulaziz University for technical support. We are grateful to Rasiq Kelassanthodi for his assistance in sampling processing.

Bakshi, M., Ghosh, S., Chakraborty, D., Hazra, S., and Chaudhuri, P. (2018). Assessment of potentially toxic metal (PTM) pollution in mangrove habitats using biochemical markers: a case study on Avicennia officinalis L. in and around Sundarban, India. Mar. Poll. Bull. 133, 157-172. doi: 10.1016/j.marpolbul.2018.05.030

Bita, C., and Gerats, T. (2013). Plant tolerance to high temperature in a changing environment: scientific fundamentals and production of heat stress-tolerant crops. Front. Plant Sci. 4:273. doi: 10.3389/fpls.2013.00273

Bongiorni, L., Fiorentino, F., Auriemma, R., Aubry, F., Camatti, E., Camin, F., et al. (2015). Food web of a confined and anthropogenically affected coastal basin (the mar piccolo of Taranto) revealed by carbon and nitrogen stable isotopes analyses. Environ. Sci. Pollut. R. 23, 12725-12738. doi: $10.1007 / \mathrm{s} 11356-015-5380-\mathrm{z}$

Caregnato, F. F., Koller, C. E., Macfarlane, G. R., and Moreira, J. C. (2008). The glutathione antioxidant system as a biomarker suite for the assessment of heavy metal exposure and effect in the grey mangrove, Avicennia marina (Forsk.) Vierh. Mar. Pollut. Bull. 56, 1119-1127. doi: 10.1016/j.marpolbul.2008. 03.019

Chen, Y., and Ye, Y. (2014). Effects of salinity and nutrient addition on mangrove Excoecaria agallocha. PLoS ONE 9:e93337. doi: 10.1371/journal.pone.0093337

Costanzo, S. D., Udy, J., Longstaff, B., and Jones, A. (2005). Using nitrogen stable isotope ratios $(\delta 15 \mathrm{~N})$ of macroalgae to determine the effectiveness of sewage upgrades: changes in the extent of sewage plumes over four years in Moreton Bay, Australia. Mar. Pollut. Bull. 51, 212-217. doi: 10.1016/j.marpolbul.2004.10.018

Das, S. K., Patra, J. K., and Thatoi, H. (2016). Antioxidative response to abiotic and biotic stresses in mangrove plants: a review. Int. Rev. Hydrobiol. 101, 3-19. doi: 10.1002/iroh.201401744

Duarte, C. M., Geertz-Hansen, O., Thampanya, U., Terrados, J., Fortes, M. D., Kamp-Nielsen, L., et al. (1998). Relationship between sediment conditions and mangrove Rhizophora apiculata seedling growth and nutrient status. Mar. Ecol. Prog. Ser.175, 277-283. doi: 10.3354/meps 175277 
Farzana, S., Cheung, S. G., Zhou, H. C., and Tam, N. F. Y. (2019). Growth and antioxidative response of two mangrove plants to interaction between aquaculture effluent and BDE-99. Sci. Total Environ. 662, 796-804. doi: $10.1016 /$ j.scitotenv.2019.01.263

Feller, I. C. (1995). Effects of nutrient enrichment on growth and herbivory of dwarf red mangrove (Rhizophora mangle). Ecol. Monogr. 65, 477-505. doi: $10.2307 / 2963499$

Feller, I. C., Mckee, K. L., Whigham, D. F., and O'neill, J. P. (2003). Nitrogen vs. phosphorus limitation across an ecotonal gradient in a mangrove forest. Biogeochemistry 62, 145-175. doi: 10.1023/A:1021166010892

Garcias-Bonet, N., Delgado-Huertas, A., Carrillo-De-Albornoz, P., Anton, A., Almahasheer, H., Marbà, N., et al. (2019). Carbon and nitrogen concentrations, stocks, and isotopic compositions in Red Sea seagrass and mangrove sediments. Front. Mar. Sci. 6:267. doi: 10.3389/fmars.2019.00267

Gong, W., and Zhang, Z. (2015). Lipid biomarkers and organic matter carbon isotopes in estuarine sediments as proxies for evaluating seawater intrusion. Estuar. Coast. Shelf Sci. 155, 38-46. doi: 10.1016/j.ecss.2015.01.016

Graniero, L. E., Grossman, E. L., and O'dea, A. (2016). Stable isotopes in bivalves as indicators of nutrient source in coastal waters in the Bocas del Toro Archipelago, Panama. PeerJ 4:e2278. doi: 10.7717/peerj.2278

Gritcan, I., Duxbury, M., Leuzinger, S., and Alfaro, A. C. (2016). Leaf stable isotope and nutrient status of temperate mangroves as ecological indicators to assess anthropogenic activity and recovery from eutrophication. Front. Plant Sci. 7:1922. doi: 10.3389/fpls.2016.01922

Habig, W. H., Pabst, M. J., and Jakoby, W. B. (1974). Glutathione S-transferases: the first enzymatic step in mercapturic acid formation. J. Biol. Chem. 249, 7130-7139. doi: 10.1016/S0021-9258(19)42083-8

Jiménez, J. J., Lorenz, K., and Lal, R. (2011). Organic carbon and nitrogen in soil particle-size aggregates under dry tropical forests from Guanacaste, Costa Rica-implications for within-site soil organic carbon stabilization. Catena 86, 178-191. doi: 10.1016/j.catena.2011.03.011

Jithesh, M., Prashanth, S., Sivaprakash, K., and Parida, A. (2006). Monitoring expression profiles of antioxidant genes to salinity, iron, oxidative, light and hyperosmotic stresses in the highly salt tolerant grey mangrove, Avicennia marina (Forsk.) Vierh. by mRNA analysis. Plant Cell Rep. 25, 865-876. doi: 10.1007/s00299-006-0127-4

Keyster, M., Klein, A., and Ludidi, N. (2012). Caspase-like enzymatic activity and the ascorbate-glutathione cycle participate in salt stress tolerance of maize conferred by exogenously applied nitric oxide. Plant Signal. Behav. 7, 349-360. doi: $10.4161 /$ psb. 18967

Khan, W., Nazre, M., Zulkifli, S., Kudus, K., Zimmer, M., Roslan, M., et al. (2017). Reflection of stable isotopes and selected elements with the inundation gradient at the matang mangrove forest reserve (MMFR), Malaysia. Int. Forest Rev. 19, 1-10. doi: 10.1505/146554817828562314

Khan, W. R., Zulkifli, S. Z., Kasim, M. R. B., Pazi, A. M., Mostapa, R., and Nazre, M. (2019). Mangrove productivity estimation using modelling approach and tree parameters assessment. Trop. Conserv. Sci. 12, 1-9. doi: 10.1177/1940082919872137

Kumar, D., Chatli, M. K., Singh, R., Mehta, N., and Kumar, P. (2016). Antioxidant and antimicrobial activity of camel milk casein hydrolysates and its fractions. Small Rumin. Res. 139, 20-25. doi: 10.1016/j.smallrumres.2016.05.002

Li, M., Xu, J., Wang, X., Fu, H., Zhao, M., Wang, H., et al. (2018). Photosynthetic characteristics and metabolic analyses of two soybean genotypes revealed adaptive strategies to low-nitrogen stress. J. Plant Physiol. 229, 132-141. doi: 10.1016/j.jplph.2018.07.009

Lovelock, C. E., Feller, I. C., Ball, M. C., Engelbrecht, B. M., and Ewe, M. L. (2006). Differences in plant function in phosphorus-and nitrogen-limited mangrove ecosystems. New Phytol. 172, 514-522. doi: 10.1111/j.1469-8137.2006.01851.x

Lovelock, C. E., Feller, I. C., Mckee, K. L., Engelbrecht, B. M., and Ball, M. C. (2004). The effect of nutrient enrichment on growth, photosynthesis and hydraulic conductance of dwarf mangroves in Panama. Funct. Ecol. 18, 25-33. doi: 10.1046/j.0269-8463.2004.00805.x

Luo, L., and Gu, J. D. (2018). Nutrient limitation status in a subtropical mangrove ecosystem revealed by analysis of enzymatic stoichiometry and microbial abundance for sediment carbon cycling. Int. Biodeter. Biodegr. 128, 3-10. doi: 10.1016/j.ibiod.2016.04.023

Mckee, K. L. (1993). Soil physicochemical patterns and mangrove species distribution-reciprocal effects? J. Ecol. 477-487. doi: 10.2307/2261526
Naidoo, G. (2009). Differential effects of nitrogen and phosphorus enrichment on growth of dwarf Avicennia marina mangroves. Aqua. Bot. 90, 184-190. doi: $10.1016 /$ j.aquabot.2008.10.001

Naidoo, G., Hiralal, O., and Naidoo, Y. (2011). Hypersalinity effects on leaf ultrastructure and physiology in the mangrove Avicennia marina. Flora Morphol. Distribut. Funct. Ecol. Plants 206, 814-820. doi: 10.1016/j.flora.2011.04.009

Naidoo, G., and Kift, J. (2006). Responses of the saltmarsh rush Juncus kraussii to salinity and waterlogging. Aqua. Bot. 84, 217-225. doi: 10.1016/j.aquabot.2005.10.002

Naidu, A. S., Larsen, L., Mowatt, T., Sweeney, M., and Weiss, H. (1982). Aspects of Sizedistributions, Clay Mineralogy and Geochemistry of Sediments of the Beautor Sea Adjacent Deltas, North Arctic Alaska. OCSEAP final Report. Anchorage: US Dept. Commerece, NOAA.

Orlandi, L., Bentivoglio, F., Carlino, P., Calizza, E., Rossi, D., Costantini, M., et al. (2014). d15N variation in Ulva lactuca as a proxy for anthropogenic nitrogen inputs in coastal areas of gulf of gaeta (Mediterranean sea). Mar. Pollut. Bull. 84, 76-82. doi: 10.1016/j.marpolbul.2014.05.036

Ouyang, S., Xiang, W., Gou, M., Lei, P., Chen, L., Deng, X., et al. (2017). Variations in soil carbon, nitrogen, phosphorus and stoichiometry along forest succession in southern China. Biogeosci. Discuss. [Preprint] 1-27. doi: 10.5194/bg-2017-408

Patel, N. T., Gupta, A., and Pandey, A. N. (2010). Salinity tolerance of Avicennia marina (Forssk.) Vierh. from Gujarat coasts of India. Aqua. Bot. 93, 9-16. doi: 10.1016/j.aquabot.2010.02.002

Polidoro, B. A., Carpenter, K. E., Collins, L., Duke, N. C., Ellison, A. M., Ellison, J. C., et al. (2010). The loss of species: mangrove extinction risk and geographic areas of global concern. PLoS ONE 5:e10095. doi: 10.1371/journal.pone.0010095

Prasad, M. B. K. (2012). Nutrient stoichiometry and eutrophication in Indian mangroves. Environ. Earth Sci. 67, 293-299. doi: 10.1007/s12665-011-1508-8

Radušien,e, J., Marksa, M., Ivanauskas, L., Jakštas, V., Çalişkan, Ö., Kurt, D., et al. (2019). Effect of nitrogen on herb production, secondary metabolites and antioxidant activities of Hypericum pruinatum under nitrogen application. Ind. Crop Prod. 139, 111-519. doi: 10.1016/j.indcrop.2019. 111519

Reef, R., Feller, I., and Lovelock, C. E. (2014). Mammalian herbivores in Australia transport nutrients from terrestrial to marine ecosystems via mangroves. $J$. Trop. Ecol. 30, 179-188. doi: 10.1017/S0266467414000054

Saravanakumar, A., Rajkumar, M., Serebiah, J. S., and Thivakaran, G. (2008). Seasonal variations in physico-chemical characteristics of water, sediment and soil texture in arid zone mangroves of Kachchh-Gujarat. J. Environ. Biol. 29, 725-732. doi: 10.1007/s11852-009-0070-y

Shahid, M., Pourrut, B., Dumat, C., Nadeem, M., Aslam, M., and Pinelli, E. (2014). Heavy-metal-induced reactive oxygen species: phytotoxicity and physicochemical changes in plants. Rev. Environ. Contam. Tox. 232, 1-44. doi: 10.1007/978-3-319-06746-9_1

Takemura, T., Hanagata, N., Sugihara, K., Baba, S., Karube, I., and Dubinsky, Z. (2000). Physiological and biochemical responses to salt stress in the mangrove, Bruguiera gymnorrhiza. Aqua. Bot. 68, 15-28. doi: 10.1016/S0304-3770(00)00106-6

Tausz, M., Šircelj, H., and Grill, D. (2004). The glutathione system as a stress marker in plant ecophysiology: is a stress-response concept valid? J. Exp. Bot. 55, 1955-1962. doi: 10.1093/jxb/erh194

United States Environmental Protection Agency. (1997). Method $3051 \mathrm{~A}$. Microwave Assisted Acid Digestion of Sediments, Sludge's, Soils and Oils. Washington, DC: USEPA; U.S. Government Printing Office. Available online at: https://www.epa.gov/sites/production/files/2015-12/documents/3051a.pdf

van Groenigen, J. W., and van Kessel, C. (2002). Salinity-induced patterns of natural abundance carbon-13 and nitrogen-15 in plant and soil. Soil Sci. Soc. Am. 66, 489-498. doi: 10.2136/sssaj2002.4890

Vuleta, A., Jovanović, S. M., and Tucić, B. (2015). How do plants cope with oxidative stress in nature? A study on the dwarf bearded iris (Iris pumila). Acta Physiol. Plant. 37, 1711. doi: 10.1007/s11738-014-1711-9

Weintraub, S. R., Wieder, W. R., Cleveland, C. C., and Townsend, A. R. (2013). Organic matter inputs shift soil enzyme activity and allocation patterns in a wet tropical forest. Biogeochemistry 114, 313-326. doi: 10.1007/s10533-0129812-2 
Wojdyło, A., Oszmiański, J., and Czemerys, R. (2007). Antioxidant activity and phenolic compounds in 32 selected herbs. Food Chem. 105, 940-949. doi: 10.1016/j.foodchem.2007.04.038

Yeomans, J., and Bremner, J. (1991). Carbon and nitrogen analysis of soils by automated combustion techniques. Commun. Soil. Sci. Plant Anal. 22, 843-850. doi: 10.1080/00103629109368458

Youssef, M., and El-Sorogy, A. (2016). Environmental assessment of heavy metal contamination in bottom sediments of Al-Kharrar lagoon, Rabigh, red sea, Saudi Arabia. Arab. J. Geosci. 9:474. doi: 10.1007/s12517-016-2498-3

Zaigham, N. A., Aburizaiza, O. S., Mahar, G. A., Nayyar, Z. A., and Al-Amri, N. (2017). Satellite remote sensing analyses for hydrogeological assessment of Rabigh drainage basin, red sea coast, Saudi Arabia. Int. J. Water Resource Arid Environ. 6, 1-12. doi: 10.4236/jwarp.2017.54041

Zhang, Z., Smittenberg, R. H., and Bradley, R. S. (2016). GDGT distribution in a stratified lake and implications for the application of TEX86 in paleoenvironmental reconstructions. Sci. Rep. 6:34465; doi: 10.1038/srep34465

Zimmermann, C. F., Keefe, C. W., and Bashe, J. (1997). Method 440.0: Determination of Carbon and Nitrogen in Sediments and Particulates of Estuarine/Coastal Water Using Elemental Analysis. United States Environmental Protection Agency, Washington, DC. EPA/600/R-15/009

Zulkifli, S. Z., Mohamat-Yusuff, F., Mukhtar, A., Ismail, A., and Miyazaki, N. (2016). Biomagnification of selected toxic trace elements (Cr, As, Cd, Pb) in a mangrove ecosystem: Insights from stable isotope analysis. Pollut. Res. $35,211-219$.

Conflict of Interest: The authors declare that the research was conducted in the absence of any commercial or financial relationships that could be construed as a potential conflict of interest.

Copyright (c) 2021 Aljahdali, Alhassan and Zhang. This is an open-access article distributed under the terms of the Creative Commons Attribution License (CC BY). The use, distribution or reproduction in other forums is permitted, provided the original author(s) and the copyright owner(s) are credited and that the original publication in this journal is cited, in accordance with accepted academic practice. No use, distribution or reproduction is permitted which does not comply with these terms. 